\title{
Critical Race Theory, policy rhetoric and outcomes: the case of Muslim schools in Britain
}

The Version of Record of this manuscript has been published and is available in Race, Ethnicity and Education (08/11/2016) http://www.tandfonline.com/10.1080/13613324.2016.1248828

Citation for this article:

Damian Breen (2016): Critical Race Theory, policy rhetoric and outcomes: the case of Muslim schools in Britain, Race Ethnicity and Education, DOI: 10.1080/13613324.2016.1248828

\begin{abstract}
The expansion of state-funded Muslim schools in Britain since 1998 has developed against a backdrop of sustained public political rhetoric around the wider position of British Muslims in both political and educational contexts. This article explores the public policy rhetoric around Muslim schools under New Labour and the subsequent Coalition and Conservative governments and compares how these narratives align with outcomes in terms of numbers of, and types of, denominational Muslim faith schools in Britain. The article applies a Critical Race Theory approach based on the construction of counter-narrative through a critical analysis of policy and its outcomes. This analysis is contextualised through exploring the implications of counter-terror strategies such as Prevent for the political and educational equity of British Muslims as stakeholders in the state. Against this context the article explores the extent to which successive policy frameworks and political narratives around faith schooling have played out in terms of denominational state-funded Muslim schools. Whilst gains have been made under New Labour and the successive Coalition and Conservative governments, critical analysis reveals that public policy narratives allow for a misleading account of the extent to which Muslim communities have been enfranchised through state funding for Islamic schools.
\end{abstract}

Keywords: Critical Race Theory; Muslim communities; Muslim schools

Damian Breen

Faculty of Health and Life Sciences, De Montfort University, Leicester, UK

Email: damian.breen@dmu.ac.uk 


\section{Critical Race Theory, policy rhetoric and outcomes: the case of Muslim schools in Britain}

\section{Introduction}

This article aims to critically consider the extent to which policy narratives around Muslim schools under both New Labour (1997-2010) and the more recent Coalition (2010-15) and Conservative (2015-date) governments line up with outcomes in terms of the numbers of Muslim schools that have been granted state funding since 1998. The article aims to explore some of the implications of the role of Muslim schools in the political enfranchisement of British Muslim communities. It is argued that Islamic schools represent a key site for British Muslims to acquire political equity in a wider climate that embodies, to varying degrees, Islamophobic discourses. The representation of Islamic schools in the independent sector demonstrates that slow progress in terms of numbers of state-funded Muslim schools is not due to a lack of demand for such schools among Muslim communities. It also logically follows that the independent sector represents fertile ground in terms of the potential numbers of Muslim schools that could be brought into partnerships with the state. Various mechanisms around faith schooling have existed in England and Wales since 1944. An important part of the argument presented here will be informed by the ways in which these frameworks have been used by Muslim communities in recent years and the wider societal implications around the 'types' of schools that each of these mechanisms results in. Some key aims inform the overall narrative of this piece. Initially the article is concerned with exploring what an intersectional Critical Race Theory (CRT)/Islamophobia analysis can tell us about the state of political enfranchisement for British Muslims in contemporary contexts. In addition to this, the article will also explore the extent to which state-funded Muslim schools represent a site for increasing political equity for British Muslims in the form of partnerships with the state. Finally, I will explore the power dynamics manifested in these partnerships and the potential implications for British Muslim communities.

\section{Establishing boundaries for the enquiry - Critical Race Theory and its application in this enquiry}

This article is focused on applying a CRT analysis of the disparity between (a) educational policy rhetoric around faith schooling generally and Muslim schools specifically since 1997, and (b) outcomes in terms of numbers of state-funded Muslim schools and the kinds of partnerships with the state that have been manifested through them. One process which is not assumed here is the conflation of religion with 'race'. It is fully acknowledged here that, whilst there are large minority ethnic groups who are Muslim such as British Pakistanis and Bangladeshis, Muslim communities in Britain are also characterised by extensive ethnic diversity (Tinker 2009). It is also acknowledged that there are bodies of work (see Allen 2010; Sayyid 2010) which critically challenge notions of Islamophobia that have been used in public documents such as the Runnymede Trust's Islamophobia - a challenge for us all (1997). The conceptual tensions that might exist around applying CRT to Muslim communities in Britain, and also the ways in which this ties into what we understand as Islamophobia, sit at the centre of other emerging work by this author. For the purposes of this article, the rationale for applying CRT when looking at state-funded Muslim schools in Britain will be based on an 
exploration of anti-Muslim sentiment in the public space and the implications of this for the political equity of British Muslims as stakeholders in both education and the state.

CRT is a theory of 'race' which has its origins in the work of critical legal scholars in the USA (Crenshaw 2002; Crenshaw et al. 1995). As a theory of 'race', CRT is fundamentally concerned with the systematic marginalisation of racialised minorities in contemporary social contexts. There are several key tenets of CRT which include Critical Whiteness Studies, master narrative and counter-narrative, interest convergence and an emphasis on the centrality of 'voice' in qualitative accounts of racism in contemporary contexts. There is not the scope to explore all of these aspects of CRT in detail in this article. For the purposes of the enquiry here the article will substantively focus on master narrative and counter-narrative in the case of state-funded Muslim schools in Britain. One of the central themes in established work on CRT has been on the ways in which policy functions to sustain 'race' inequalities across education (see Gillborn $2005,2008)$. To this end the enquiry here is informed by a critical consideration of public policy and rhetoric around faith schooling since 1997 with a view to comparing narratives around Muslim schools in the political and public space with outcomes. A recurring theme in emerging CRT scholarship focused on policy analysis has been the argument that societal structures ensure that 'racial' inequity is sustained at the biting point of tolerable discomfort for marginalised racialised minorities. This article will ultimately argue that there has been a disconnect between public narratives around Muslim schools and real outcomes in the form of numbers. Therefore, access to state-funded Muslim schools remains largely exclusive for the vast majority of British Muslims. These outcomes sit against a backdrop of policy rhetoric which acknowledges the tendency for faith schools to perform strongly in educational league tables.

On the surface, applying a theory of 'race' to look at issues around religion might seem at best restrictive and at worst problematic. The safest option might be to simply focus on one particular ethnic group within the wider religious community of British Muslims. In many ways this would be completely unproblematic, particularly if the analysis retained a clear set of boundaries around how far arguments might be applicable in terms of clearly identified ethnic groups. However, using CRT in this constrained way raises issues around power, knowledge and the purpose of CRT as an emancipatory framework focused on revealing the fullest extent to which 'racial' inequalities are manifested in contemporary social contexts. Applying CRT in the analysis of only certain Muslim communities could arguably contribute to power dynamics around knowledge and the purpose of knowledge which reinforce a 'divide and conquer' effect. There are some important arguments around master narratives, counter-narratives and the purpose of CRT which will need to be considered in order to fully demonstrate this point, and they will be explored in greater detail later in this article. It is important that the premises for the application of CRT to Muslims as a religious community are effectively established by exploring the ways in which British Muslims are systematically racialised in the public sphere.

\section{Islamophobia?}

The foundation for establishing a convincing case for applying Critical Race Theory in the analysis of Muslim communities can be established through considering the ways in which Muslims have been marginalised as a religious group. Once we establish the forms in which this takes we can set out the premises for identifying the particular dynamics of discrimination 
faced by Muslims. Existing bodies of work on Islamophobia have consistently demonstrated the ways in which Muslims have received sustained negative media attention, particularly in the years following 11 September 2001 and the London bombings of 2005. It is fully acknowledged here that there is much critical discussion around Islamophobia and what it means at the conceptual level. There is not the scope to substantively replicate these arguments in their entirety here. However there are some key points in these emergent discussions on Islamophobia that can be explored further for the purpose of the argument here. Initially, we do need to consider what 'Islamophobia' might refer to, and how we might initially identify the phenomena as it is articulated and manifested in the public sphere. As part of a far more critical exploration of Islamophobia at the conceptual level, Allen (2010) argues that a distinct 'Muslim' or 'Islamic' identifier or identification process would appear to be an essential feature (Allen 2010, 62). Allen's identification of this 'initial identification process' is part of a wider critique of notions of Islamophobia that had been used in the public space, most notably within the seminal Runnymede report Islamophobia - a challenge for us all (1997). The report identified Islamophobia as being manifested in three 'closed views' of Islam. The first of these closed views is the perception of Islam as being seen as a 'single monolithic bloc, static and unresponsive to new realities' (Runnymede 1997, 5). The overtones here are twofold. Firstly, Islam is presented as homogenous rather than diverse. Secondly, it is suggested that Muslim communities are unresponsive to change. If Muslim communities are perceived of as being unresponsive to change, then the implication here is that the scope for resolving any perceived conflicts is minimal. This first interpretation is closely related to a second 'closed' perspective which identifies Islam as separate and 'other', with aims and values being posited in opposition to and resistant of the influence of other cultures (Runnymede 1997, 5). Allen critiques the use of these closed views arguing that they suggest a homogenised notion of Islamophobia which does not effectively allow for the inclusion of the many nuanced and varied ways in which anti-Muslim and anti-Islamic phenomena might occur (Allen 2010, 55). Thus, if we are confined to identifying Islamophobia by the reference points in the Runnymede report, much anti-Islamic or anti-Muslim phenomena are likely to fall under the radar.

If we draw on this critique as a descriptive process it is easy to see parallels with the ways in which racism is discussed in Critical Race Theory. A key tenet of Critical Race Theory is the notion of racism as becoming less explicit, more nuanced and subtle and thus largely evading identification in the white experience of master narratives. An interesting explanation around the ways in which this impacts specifically for Muslim communities is offered by Sian (2015). She argues that the racialisation of Muslims occurs in the context of the dismissal of racism and its critique in general society (Sian 2015, 196, 197). This conviction is consistent with wider CRT narratives which identify the power of racism in contemporary contexts as coming from the ways in which it evades identification as a result of the wider societal adherence to post-racial logics. Furthermore, we can also identify the Runnymede report as a political piece of apparatus that actually facilitates anti-Muslim and anti-Islamic 'phenomena' whilst purporting to do the exact opposite. Of central relevance here is the work of S. Sayyid who raises the question of whether Islamophobia is closer to 'anti-semitism' or 'racism' (Sayyid 2010). He offers a comprehensive discussion which draws a series of comparisons between these phenomena. Constraints do not allow for the replication of this discussion here, however key comparisons include differential public perceptions between Islamophobia and anti-semitism. For example, Sayyid argues that anti-semitism is accepted as an unprovoked 
phenomena, whereas 'some Muslims are accused of contributing to Islamophobia'. Muslims are differentiated into groups identified as 'good' and 'bad' (Sayyid 2010, 11). This also spills over into differential expectations for Muslims to provide public statements of regret around violent conflicts that may happen across religious lines (Sayyid 2010,11).

Similarly, Sayyid argues that Islamophobia does not necessarily fit with, what he identifies as, a Eurocentric conception of racism that requires the presence of racists (Sayyid 2010, 12). It is this critical turn that serves as a key step here towards integrating Islamophobia with CRT. Whilst not exclusively the case, racism within a CRT framework certainly includes the acknowledgement of racist outcomes without the necessary presence of active racists. As noted above, a key part of the CRT argument is that racism has become so nuanced that it evades detection in mainstream society. This argument relies on the premise that racist outcomes are not necessarily exclusively the result of the behaviours of active 'racists'. Thus, whilst Islamophobia might not fit with the 'Eurocentric concept of racism' as it is identified by Sayyid, the more nuanced model of racism at the centre of much CRT enquiry might share some fundamental consistencies with Islamophobia. Sayyid argues that racialised bodies have never been exclusively biological, rather they emerged alongside the identification of religion, culture, history and territories which were used to group fabricated distinctions between 'Europeanness' and 'non-Europeanness' (Sayyid 2010, 13). For Sayyid, Islamophobia can arguably be defined as the disciplining of Muslims by reference to an antagonistic 'Western' horizon (Sayyid 2010, 15). For the purposes of the article we can identify that, whilst Islamophobia is nuanced and complex, at its core it implicates the presence of a wider antiIslamic phenomena which positions Muslims as 'non-European' in European public political settings. The article will now move on to consider some of the wider implications here for the political enfranchisement of British Muslims in the public space more generally, before focusing on the state of educational enfranchisement through the development of statefunded Muslim schools more specifically.

\section{Prevent - implications for political and educational equity}

One of the mechanisms through which Muslims have been displaced as stakeholders in mainstream political equity is through the residual effects of counter-terror strategies. Kundnani (2009) argues that the logic of the 'Prevent' branch of the counter-terrorist strategy in Britain has been counter-productive, and actually serves to perpetuate tensions between British Muslim communities and the state. The Prevent strategy was launched in 2007 as part of the British government's wider counter-terrorism strategy and has been focused on a 'community-led' approach to preventing violent extremism (Kundnani 2009). The rationale for Prevent was to 'win over hearts and minds' of young Muslims in Britain and to lead them away from extremist narratives (Kundnani 2009, 10). At the early stages, the strategy involved the allocation of funding to local authorities for the purpose of targeted capacity building of Muslim communities particularly focused on young people, women and Mosques (Kundnani $2009,10)$. Central to the Prevent agenda has been the promotion of shared values to challenge extremist ideologies and strengthening the role of faith institutions within those communities. These developments have led to a focus on education standards in general and citizenship education specifically in after-school supplementary provision offered in Mosques, Madrassas and Muslim community organisations (Thomas 2009, 284). However, the 'Muslimcentred' focus within strategies like Prevent functions as something of a self-defeating contradiction, given the evidence that indicates that wider segregation across ethnic and 
religious lines has been the context within which radicalisation has occurred, at least in the British context (Thomas 2009, 285). Even if we were to ignore this contradiction, Kundnani argues that serious problems arise when deprived communities in need of support consider that their voluntary sector organisation can only access resources to meet their needs if they are willing to sign up to a counter-terrorism agenda (Kundnani 2009, 10). Furthermore, the allocation of funding within this Muslim-specific approach has the potential to fuel White, working-class resentment, whilst leaving some Muslims feeling that they have been targeted as a result of broad, negative generalisations about their communities (Thomas 2009, 285, 286). But there are wider issues here with the ways in which funding has been allocated. Rather than distributing economic resources based on need, funding for 2008-2011 was allocated across cities proportionate to the size of their Muslim communities (Kundnani 2009, 13). Allocating funds in this way reveals a wider discursive set of assumptions about 'need' relative to the scale of a Muslim presence in a particular space. Invariably, this demonstrates one of the ways in which the Prevent strategy has been informed by a myriad of Islamophobic logics whereby young Muslims are subject to various forms of racialised governmentality (Sian $2015,197)$.

There is a more pervasive effect of counter-terror strategies for Muslims as communities in European settings at a time where public political interests are characterised by the 'war on terror'. For example, Fekete argues that the culmination of European security strategies and counter-terrorist policies which have emerged out of public and media narratives around the 'war on terror' represent a structured anti-Muslim racism (Fekete 2004). According to Fekete, these security strategies 'lump together genuine political dissidents and numbers of ordinary Muslims with individuals whom most would regard as terrorists, thus obfuscating rather than clarifying any possible genuine threat' (Fekete 2004, 9). Fekete's concept of anti-Muslim racism goes beyond simply identifying that Muslims experience racialisation as a result of political narratives around the 'war on terror'. Rather, anti-Muslim racism is organised and operates discursively. Fekete argues that intelligence services, police and the media work in conjunction with a political agenda centred around eliciting public consent to surveillance through the evocation of fear, to create a culture of suspicion against Muslims (Fekete 2004, 14). This culminates in Muslims being identified as and policed as a suspect community (Fekete 2004, 10).

There are some interesting implications of the point raised by Fekete, particularly regarding ordinary political dissidents. Counter-terrorism policies and security strategies have resulted in environments whereby the political voices of young Muslims are subject to a dual process of scrutiny and displacement from mainstream democratic discussion. For example, part of the process of identifying radicalisation necessitates an evaluation of an individual's political orientation. Counter-terrorist strategies provide a normative base from which these judgements are made, and therefore British Muslims who are particularly outspoken and oppose the involvement of European nation states in conflicts in Islamic countries become at risk of being labelled as 'radical'. Conversely, the exact same argument could be articulated by a non-Muslim individual without carrying any risk of being labelled in the same way. It is also important to consider here that, within the UK context, wider public policy documents consistently avoid applying the term 'violent extremism' to any other ethnic, or religious, group (Thomas 2009, 284). The Muslim-centred focus within Prevent in particular results in an agenda which claims even-handedness, but allows the continuing development of 
organisations like the British National Party (Thomas 2009, 286) and the English Defence League. These kinds of public narratives result in Muslim political voices being subjected to a filtration process which has the power to displace particular political interests outside of mainstream democratic discussion. The inability for counter-terrorism strategies to effectively differentiate Muslim political dissidents indicates that these strategies homogenise Muslims based on the kind of 'closed views' of Islam identified by Runnymede in 1997. Inevitably, for Muslims, engaging in political democratic debates becomes weighted with risk and suspicion. In line with Fekete's argument, this constitutes a discursive process whereby the legitimacy of political voices is determined based on an individual's identity as being either Muslim or non-Muslim.

As noted above, such counter-terror strategies have massive implications for the political marginalisation of British Muslim voices owing to the risk of conflating Muslim political dissidents with Islamic extremists. However, the political marginalisation of British Muslims also happens at a far more subtle level and this is inherently embedded in conventional notions of 'race' which exclude religious identity as a legitimate facet. As argued by Meer \& Modood, 'while curbs on the defamation of conventionally conceived ethnic and racial minorities might be seen as progressive, the mocking of Muslims is seen to constitute healthy intellectual debate' (Meer and Modood 2009, 348). Thus, although we have established that religious identity is no more chosen than prescribed racial categories for those who are born into a Muslim families, Muslims as a minority group are not afforded the same protections against anti-Islamic sentiment that other racialised groups are against racism. This sidelining of Muslim interests can be explained as a direct effect of a dominant public perception which sees Muslims as a threat rather than a disadvantaged minority subject to increasingly pernicious discourses of racialisation (Meer and Modood 2009, 354). Whilst the kinds of antiMuslim sentiment outlined by Meer \& Modood may have their roots in notions of cultural racism, anti-Muslim sentiment also has fundamental implications for the political disenfranchisement of British Muslims. Anti-Muslim racism may well have its roots in notions of cultural racism centred around identifying 'good' and 'bad' South Asians as identified by Modood (2005) and Hussain and Bagguley (2012), but the racialisation process is farther reaching and impacts across the political struggle between Muslims and the state that are borne out of counter-terror strategies like Prevent.

The discussion above is not only relevant to debates about the wider impact of counter-terror strategies on political equity and the differential legitimacy afforded to voices of dissent in democratic politics. The Prevent strategy and its appendages (most recently the statutory duty for schools to prevent violent extremism) manifest a bridging gap between political equity and education indicating a wider culture of surveillance around Muslim children in schools. This is bound into wider public narratives around the conflating of increased Islamic influence with legitimate threat. This binary reading of the Islamic in the public space completely overlooks one of the key functions of Muslim schools as identified in the voices of stakeholders in Islamic schools in Meer's research (2009). Meer cites Abdullah Trevathan (head of the Islamia school in Brent) as explicitly stating in an interview that part of the purpose of Muslim schools is to create an emerging British Muslim culture, rather than the conservation of any pre-existing culture (Meer 2009, 383). In this particular instance, the increased presence of the Islamic in the public sphere that necessarily comes with Muslim 
schools equates with negotiating a space affording educational and civic gains for British Muslims.

\section{Muslim schools in England and Wales}

Muslim schools have been present in England and Wales since 1979 (Dooley 1991). It is important to establish here that, whilst many Muslim children receive supplementary Islamic education through the provision of Madrassas in community Mosques, this paper is concerned with those institutions which are registered as Muslim schools either in the independent or state-maintained sector in England and Wales. Within the frameworks around state-maintained education, particular types of schools are able to identify as having a 'distinctive religious character'. There are two important timeframes to consider here with regard to policy structures and faith schooling. The first state-maintained Muslim schools were established in England and Wales in 1998, and so it logically follows that our starting point should be to explore the frameworks in place at that time. The notion of a 'distinctive religious character' was first introduced under New Labour with the School Standards and Framework Act (UK Parliament 1998). Under the Act, voluntary-aided schools are permitted to identify themselves as having a 'distinctive religious character' whilst providing denominational Religious Education (RE) in line with their religious character. Arrangements for funding represent an important distinguishing feature of voluntary-aided schools, with costs for individual institutions being met by both the state and a religious organisation affiliated with a given school. The proportion of cost to be covered by each party has changed over time, but in the period between 1998 and 2010 voluntary-aided schools would receive up to $90 \%$ of their funding from the state with the outstanding $10 \%$ being met by an affiliated religious organisation (DfES 2002) such as a Church, Mosque or Synagogue. Independent schools are able to register a distinctive religious character under the Designation of Schools Having a Religious Character (Independent Schools) (England) Order 2003. The next section will consider the developments around Muslim schools under the frameworks around faith schooling under the Labour government between 1998 and 2010 in further detail. We will then move on to outline how structures around faith schooling changed under the Coalition government of 2010-15.

\section{New Labour: a sustained interest in state-funded minority religious schooling?}

Within the last 30 years there have been a series of changes in the policy frameworks around state provision for faith schooling that have impacted on Muslim schools. The 1993 Education Act first introduced frameworks which would allow independent faith schools to apply for funding directly through central government. Under these frameworks, regulation of the school would also come directly from central government rather than the local education authority. This process would position independent faith schools successful in securing grantmaintained status outside of any local communities of voluntary-aided faith schools. However, it would nevertheless provide an effective mechanism for two Muslim schools, Islamia Primary and Al-Furqan, to successfully be the first to secure state funding in England and Wales (Tinker 2009, 540). These two schools inevitably transitioned into the voluntaryaided sector following the phasing out of grant-maintained status in 1999. It is worth noting here that these initial advances were made under the New Labour government elected in 1997. The sustained interest in faith schooling and the emphasis on encouraging independent minority faith schools to enter the state sector represented a recurring theme within New Labour's wider 'education, education, education' (Coughlan 2007) mandate. 
The apparent interest in funding minority religious schools more generally, and Muslim schools specifically, was manifested in a series of parliamentary papers and public documents under New Labour. For example, the 2001 Green Paper Schools building on success emphasised that faith schools appear to perform well when compared to non-denominational schools, and subsequently proposed expanding faith-schooling within the state sector (DfEE 2001). In 2005, the White Paper Higher standards, better schools for all continued this narrative by further encouraging independent schools to join the state sector, with a particular emphasis on encouraging Muslim schools to apply for voluntary-aided status (UK Government 2005). Furthermore, in September 2007 the government, along with representatives of major faith groups, released the document Faith in the system. The paper 'unveiled a joint declaration and shared vision of schools with a religious character in twentyfirst century England', stating that the government recognises the aspirations of faith communities to secure more schools to offer education in accordance with the tenets of their faith (DCSF 2007, 4). Faith in the system again placed a particular emphasis on encouraging minority religious schools to apply for state funding, stating that there are

15,000 Muslim children and around 11,000 Jewish children, including those from lowincome families, whose parents chose to send them to independent schools with a particular religious character and that the availability of places in the maintained sector could therefore provide an important contribution to integration and empowerment of these communities. (DCSF 2007, 18).

Under the Labour government the number of voluntary-aided Muslim schools in England and Wales rose steadily and currently stands at 12, a figure which has not changed since 2010 (Breen 2013). New Labour's sustained policy narratives around encouraging the establishment and subsequent expansion of state-funded Muslim schools invariably culminated in real and objective economic gains for British Muslim communities.

\section{Anxiety following $\mathbf{2 0 1 0}$ ?}

The arrival of the Coalition government in 2010 and subsequent Conservative government in 2015 has provided for a confused picture regarding the government's position on faith schools. The political landscape since 2010 has been complex, with a series of developments leaving the future of minority faith schooling open to question. Almost immediately after securing office as Prime Minister David Cameron declared that 'state multiculturalism has failed' (Helm, Taylor, and Davis 2011), a statement that necessarily brings into question the issue of whether or not the state will continue to encourage faith schooling for minority communities. However, the wider implications of the change in government in 2010 for statefunded faith schools generally, and Muslim schools specifically, are far from clear. One key development in education policy came with the Academies Act of 2010 which laid the foundation for the widespread 'conversion' of state schools to academy status, including vast swathes of voluntary-aided schools. The Academies Act also set out the frameworks around 'free schools' which can be established to serve the interests of local communities (UK Parliament 2010). Thus, at least in theory, the frameworks around free schools might provide opportunities for Muslim communities to found Islamic schools and secure state funding for them, even in the light of Cameron's apparent convictions around multiculturalism. 
It is worth noting here that David Cameron used the term 'state multiculturalism', implying that it is multiculturalism as an institutionalised strategy, advocated in the Swann Report (1985), that has failed. As an institutional strategy 'state multiculturalism' has been criticised for lacking clear guidelines and national leadership (Parekh 2000), and consequently failing to effectively embody the conceptual premises of 'multiculturalism' as a conceptual tool for challenging 'race' inequality (see Meer and Modood 2009; Modood 1994, 1998, 2008; Modood and Werbner 1997). However, the declaration that multiculturalism has failed represents only one example of the wider revival of assimilationist discourses around education following the events of 11 September 2001, the 2001 riots in the North of England and the London bombings of 7 July 2005 (Sian 2015, 183). Evidence of the revival of assimilationist discourses around education has most recently been revealed with the anxieties around the Trojan Horse letter in Birmingham. Whilst raising some concerns, lan Kershaw's investigation into the Trojan Horse letter ultimately concluded that there was not evidence to suggest there was 'a systematic plot to take over schools' (Kershaw 2014, 8). The details around Trojan horse are complex and there is neither the scale or scope to explore these in depth here. However, subsequent public debates around Trojan horse did further demonstrate the presence of wider anxieties around the Islamic as representing a threat to British values in the public sphere. Such concerns about increased Islamic influence in the education sector might be more about Muslim schools representing an anathema to assimilation rather than any real 'risks'. The above discussion necessarily raises questions as to what the future might look like for Muslim schooling in the state sector. Short of halting the expansion of state Muslim schools specifically, it would appear that the Academies Act may serve as a strategy for facilitating more Muslim schools, but only on the condition that, in the event of any issues, all responsibility is devolved to individual institutions.

In addition to the developments above, the future of state-funded Muslim schools also comes into question when considering the wider economic conditions that have dominated political debates around public spending following the onset of the recession in 2008. In particular, the Coalition and subsequent Conservative governments both placed economic recovery at the centre with widespread implications for cuts in public spending. Following the general election of 2010, the Coalition government's primary strategy for economic recovery was most notably manifested in a series of 'austerity measures' which have been carried over with the election of a Conservative majority government in 2015. Political and economic conditions since 2010 represent something of a U-turn in levels of state support for the expansion of Muslim schools in the state sector. The question around the extent to which Muslim communities will be able to continue to make gains through quantifiable outcomes is of central relevance. However, recent economic and political events have also impacted on faith schools in far more nuanced ways. The advent of the Academies Act in 2010 has posed existing voluntary-aided schools with the dilemma of weighing up the opportunity cost of retaining their existing status in a competitive and transformative education market against the possible benefits of converting to academy status (Meer and Breen forthcoming). Existing figures demonstrate that this dilemma is impacting on voluntary-aided schools with $33 \%$ converting to academy status by 2013 (Bolton 2013, 4). Breaking these figures down across denominations reveals that Church of England ( $C$ of $E$ ) schools appear to be most active in converting to academy status with $41 \%$ of $C$ of $E$ voluntary-aided schools having done so by 2013 compared with 25\% of Roman Catholic schools (Bolton 2013, 4). Such transformative trends within the maintained sector are likely to result in new challenges for both existing 
state-funded Muslim schools and stakeholders in Muslim communities looking to make future gains in denominational schooling.

\section{Numbers of British Muslim schools}

In order to gain an accurate picture of how Muslim schools have been positioned under the Coalition and subsequent Conservative governments, it is important to establish how far Muslim communities have been enfranchised through state funding for Islamic schools to date. Furthermore, it is crucially important to consider the ways in which any gains have been made and the nature of the partnerships that they represent. The discussion in the previous subsection might appear to champion multiculturalism due to ways in which statemulticulturalism has informed outcomes in terms of enfranchising Muslim communities through state funding for Islamic schools. It is important to note here that the establishment of state-funded Muslim schools under New Labour did represent a watershed in the educational enfranchisement of British Muslims. Particularly, the establishment of Muslim voluntary-aided schools represents a critical step in bringing Muslim communities into partnerships with the state (Meer 2007, 67, 68). However, it is an understanding of both how gains have been made prior to 2010 and also the implications for future partnerships with the state after 2010 that position this work firmly within a Critical Race Theory Framework.

The development of voluntary-aided Muslim schools arguably represents the clearest and most tangible example of educational enfranchisement for religious Muslims. Whilst this is significant, in reality only limited numbers of independent Muslim schools have successfully made the transition into the voluntary-aided sector. As noted above, the central relevance of Critical Race Theory here is most clearly established through understanding two key factors that need to be considered chronologically in order to avoid confusion. Firstly, the conditions around the initial establishment of state-funded Muslim schools between 1998 and 2010 need to be explored. Secondly, we need to consider what the landscape looks like following the Academies Act of 2010 and the implications of current political conditions for the future of state-funded Islamic schooling. If we focus initially on developments prior to the advent of the Academies Act 2010, we can establish how far Muslim communities were enfranchised under New Labour relative to other religious groups. In 2009 there were approximately 7000 voluntary-aided schools in England with the vast majority being Church of England (C of $E$ ) or Roman Catholic (Tinker 2009, 540). Within this number, 53 voluntary-aided schools had a distinctive religious character other than C of E or Roman Catholic (Tinker 2009, 540). Breaking these schools down across religious character reveals that those 53 schools comprised 37 Jewish, 2 Sikh, 1 Greek Orthodox, 1 Seventh Day Adventist (Tinker 2009, 540), and 12 Muslim (Breen 2009, 111). By way of comparison, the vast majority of Muslim schools (approximately 120 at the same point in time) lie within the independent sector (Breen 2013, 42). As noted above, the establishment of state-funded Muslim schools in England and Wales represents a significant step forwards in terms of the educational enfranchisement of British Muslims. However, comparing outcomes in this way reveals that, although tangible gains can be identified with the establishment of 12 Muslim schools in the voluntary-aided sector by 2009, 10 times this number were residing in the independent sector (Breen 2013, 42). Thus, the vast majority of British Muslims attending Islamic schools were doing so outside of any partnership with the state. 
Whilst the above starts to reveal just how few British Muslims have had the benefit of attending a voluntary-aided Muslim school, a crucially important point needs to be acknowledged here. Numbers of Muslim schools within the independent sector have a tendency to fluctuate for two main reasons. Firstly, independent Muslim schools face ongoing financial instability in the struggle to economically sustain themselves (see Breen 2009, 2013, 2014). Within these contexts the threat of closure is a constant risk and some schools will be unsuccessful in finding economic sustainability. Secondly, numbers of independent Muslim schools necessarily change as and when any such schools enter the state sector. These two factors have informed the ways in which numbers of independent Muslim schools have been discussed in England and Wales. Consequently, between 2009 and 2013 numbers of independent Muslim schools were estimated at approximately 120 (2015). Increased access to publicly available data indicates that numbers of Muslim schools in the independent sector appear to be growing with current numbers totalling 158 (AMS data as of October 2014). In the wake of acknowledging the difficulties around identifying exact numbers of independent Muslim schools, it is still clear that the proportion of Muslim schools which have successfully entered the state sector is small. Even based on an approximation, it can still be safely argued that the representation of Muslim schools in the independent sector prior to 2010 was at least tenfold that represented in the state sector.

The trend with Muslim schools outlined above becomes particularly interesting if we compare numbers of Church of England and Roman Catholic schools across independent and statemaintained sectors. Within the independent sector there are currently $564 \mathrm{C}$ of $\mathrm{E}$ schools (CofE 2013) and 146 Catholic schools (CES 2012) compared with 4800 C of E schools (Chadwick 2012) and 2166 Catholic schools (CES 2012) in the state-maintained sector. Therefore, it is clear that proportional representation across sectors appears to be inverted when comparing state-funded Christian and Muslim provision. Clearly, educational provision for Christian schools is predominantly provided for within the state sector, whereas provision for Muslim schooling is predominantly provided for within the independent sector. It might not be realistic to expect to see Muslim communities having the same proportional access within each sector as that afforded to Christians. Nonetheless, drawing this comparison demonstrates just how small the gains for Muslim schools were between 1998 and 2010. In particular, given the sustained policy rhetoric inviting Muslim schools to enter the state sector under New Labour, it is important to ask why only 12 schools successfully made this transition between 1998 and 2010. The success rate appears to be quite low considering the numbers of Muslim schools that are operating in the independent sector.

The misalignment between New Labour's sustained policy rhetoric around Muslim schools and the outcomes that British Muslims have subsequently acquired reflects a legacy of struggle faced by independent Muslim schools seeking to acquire state funding. Whilst Muslim schools have been active in the pursuit of state funding as early as 1983 (see Tinker 2009, 540), it is 1998 before we see the first state-funded Muslim schools in England and Wales. An explanation for this is offered by Walford, who argues that strict financial and demand-led criteria imposed at the time made it difficult for evangelical Christian schools and Muslim schools to enter the state system (Walford 2003, 165). The challenges faced by independent Muslim schools seeking to enter the state sector have been well documented. As noted earlier in this chapter, the Islamia primary school in Brent was the first independent Muslim school to be awarded state funding through grant-maintained status in January 1998 
(Tinker 2009, 540). The school had initially started to explore possibilities around acquiring state funding in 1983 and submitted a formal application in 1986 (Tinker 2009, 540). This application was considered and rejected in 1990 as was a follow-up application in 1993 (Tinker $2009,540)$. In 1995 a final application was made which resulted in the school being awarded grant-maintained status in 1998 following a 15 year struggle for state funding (Tinker 2009, 540). Al-Furqan, the second school to successfully attain grant-maintained status, fought a four-year campaign before receiving state funding in September 1998 (Parker-Jenkins, Hartas, and Irving 2005, 44). Similarly, Feversham College in Bradford initially applied for state funding in 1994, but did not successfully enter the voluntary-aided sector until six years later in 2000 (Tinker 2009, 540). In the case of Islamia and Al-Furqan the struggle for state funding began well before New Labour came to power, and ended under that government. However, Feversham College endured a lengthy struggle similar to that of Al-Furqan, much of which took place under New Labour. Whilst this is only one documented case, it is important in demonstrating that acquiring state funding for Muslim schools was still characterised by struggle after the change of government in 1997. This point is further demonstrated in the low numbers of Muslim schools that successfully qualified for voluntary-aided status prior to 2010. Thus, New Labour's rhetoric around inviting independent Muslim schools to enter into partnerships with the state may have served as a smokescreen to obscure an unseen tacit intentionality focused on offering only marginal gains. From this position, New Labour appear to be progressive, able to commend themselves on offering the first state-funded Muslim schools, whilst ensuring that the criteria for doing so effectively prevents widespread enfranchisement for British Muslims

\section{Issues around faith schooling and Muslim schools post-2010}

The disparity between policy rhetoric and outcomes in terms of numbers of state-funded Muslim schools under New Labour played out in the form of marginal gains in the state sector for British Muslims. However, the arrival of the Coalition government in 2010 and the subsequent Conservative government of 2015 represents something of a game changer in terms of how policy plays out for stakeholders in Islamic schooling. As demonstrated above, the landscape of state-funded Islamic schooling between 1998 and 2010 was largely characterised by slow-paced and hard-fought gains being secured through the voluntaryaided system (Meer and Breen, forthcoming). Demand for Muslim schools also appears to be on the increase with numbers of independent Muslim schools seemingly rising. As noted above, numbers of independent Muslim schools around 2009-2013 were estimated at approximately 120 (Meer and Breen, forthcoming). More recent figures place numbers of independent Muslim schools at 158 (AMS data as of October 2014). As noted above, there are some difficulties with establishing exact numbers of independent Muslim schools due to the impact of financial instability being manifested through fluctuating numbers. Owing to the difficulties in establishing exact numbers in recent years, it would be problematic to claim objectively that numbers of independent Muslim schools have risen by 38 since 2009 . However, the number standing at 158 as of 2014 certainly demonstrates that Islamic schooling is in demand. Furthermore, we can identify that it is likely that some growth has taken place in the independent sector, even if negating factors make it difficult to quantify progress in precise terms.

Alongside the apparent growth of Muslim schools in the independent sector, numbers of state-funded Muslim schools have increased since 2010 and at a relatively fast rate compared 
with the 1998-2010 era. Rather than favouring the voluntary-aided sector, gains in terms of state-funded Muslim schools are now being made most notably following the shift in policy manifested in the Academies Act 2010 (UK Government 2014). In addition to championing academies, the Academies Act (2010) set out the framework for Free Schools as a mechanism for 'communities and faith groups' (UK Government 2014) to develop schools to cater to local needs. Whilst the number of voluntary-aided Muslim schools has remained at 12 since 2009, in subsequent years the number of state-funded Muslim schools in England and Wales has risen to 21 (AMS data as of October 2014). The most substantive gains since 2010 have been made through the new and emergent frameworks around free schools. Currently, the landscape of state-funded Muslim schooling comprises 12 voluntary-aided schools, eight free schools and one academy (AMS data as of October 2014). Although the number of voluntaryaided Muslim schools has remained at 12 since 2009, it is important to point out that the single Muslim academy was previously operational in the voluntary-aided sector. This means that at some point following the Academies Act (2010) one voluntary-aided Muslim school made the transition to academy status leaving 11 Muslim schools in the voluntary-aided sector. Given that the number currently stands at 12 , this suggests that one independent Muslim school has successfully entered voluntary-aided sector since 2010. It is also worth identifying a further point of clarity here, in that many independent Muslim schools use the term 'academy' in their name. However, as independent schools, these institutions are entirely privately funded and are not 'academies' in terms of the criteria and frameworks set out for state-maintained schools under the Academies Act 2010. Nevertheless, the tendency for independent Muslim schools to refer to themselves as 'academies' may have distorted public perceptions of how far Muslim communities have become educationally enfranchised since 2010.

\section{Gains made in the post-2010 era}

As noted above, the most notable gains that have been made post-2010 in terms of statefunded Muslim schools have taken place through the frameworks around free schools. Whilst it seems that objective economic enfranchisement has been on the rise for Muslim communities seeking state funding for their faith schools, deconstructing the structures around free schools reveals something of a counter-narrative in the CRT sense. An overall increase in the number of state-funded Muslim free schools since 2010 might appear to demonstrate the suitability of the Academies Act as a strategy facilitating a sustained commitment to increasing educational equity for British Muslims. However, the dynamics of the relationship between local stakeholders and the state is fundamentally different to that which has been manifested in the voluntary-aided Muslim schools established between 1998 and 2010. Voluntary-aided schools operate within local authority control. In the pre-2010 era this had meant that state-funded denominational faith schools within a given local authority effectively constituted a network of institutions working in direct relation to local government. Whilst resources invariably impact on real-life experiences, within this dynamic it is at least possible for the local authority to work in conjunction with schools to meet the needs of local communities. The Academies Act (2010) represents an important watershed in the erosion of the role of government in the maintained sector. Free schools operate outside of local authority control and as such are answerable only to central government as do academies. Trends discussed above demonstrate that voluntary-aided schools are slowly but surely converting to academy status and so the role of local government in educational provision is steadily changing. Whilst these developments are presented in ways which 
highlight the 'freedoms' afforded by stepping out of local government control, in reality any liberation is afforded at the cost of massively increased individual accountability for schools. The 2010 Act arguably represents the manifestation of uber neoliberal principles around education and the shifting of accountability for its provision away from local government. However, of crucial importance here, the nature of the relationship between schools and central government is fundamentally different to that manifested in a system under local education authorities. In the post-2010 era all schools that convert or operate under academy or free school status do so in partnership with central government. From a purely logistical standpoint, this system cannot possibly offer the same level of presence and support that is possible in the partnerships manifested in voluntary-aided schools.

A clear example of this can be seen with the ways in which media narratives have been constructed around the Al-Madinah free school in Derby, UK. Since the advent of the Academies Act (2010) and the Coalition's commitment to advocating academies and 'free schools', there has been some increase in the number of Muslim schools in the statemaintained sector. In addition to the 12 voluntary-aided Muslim schools, there are now eight Muslim free schools and one Muslim academy (AMS 2014). Since 2010 then the total number of state-funded Muslim schools has risen from 12 to 21, with the predominant gains being made through the mechanism of 'free schooling'. This is consistent with the rhetoric around 'free schools' as mechanisms for communities to establish schools which suit their local needs from the ground up. However, whilst this has yielded gains for Muslim communities, this has taken place against a sustained backdrop of public concern around Muslim free schools in the media. This is demonstrated in the case of Al-Madinah, which has seen sustained negative media attention as a result of concern from OFSTED, the Education Funding Agency (EFA) and the Department for Education (DfE). The Al-Madinah School in Derby opened in September 2012 as the first Muslim free school to offer provision at nursery, primary and secondary levels. The school was investigated for 'financial irregularities' in August 2013, and an OFSTED report which followed raised further concerns about the school (BBC 2013). Much media speculation has been generated around the nature of the concerns raised by OFSTED, with references being made to girls being made to wear compulsory hijabs(headscarves) and segregated classes (BBC 2013). Whether these concerns are or are not realised or evidenced in the public space remains to be seen.

However, there are two important points which can be raised when considering the case of Al-Madinah. The first of these is concerned with the contextual points of reference which have been used in media discussions. The problems which have been raised have been consistently attributed to the school's faith character, rather than its position as a free school operating within new and emergent educational structures. At least one other free school has also faced closure in the 'Discovery' school in Crawley (Adams 2013), whilst funding was pulled from the 'One in a Million' free school in Bradford nine days before it was due to open (Beckett 2012). This evidence demonstrates that there have been systemic problems with the structures around free schools. However, when Al-Madinah is discussed in the media, problems have been primarily attributed to the school's faith status, rather than the wider systemic problems around free schools. A second point which can be raised with regard to the case of Al-Madinah is that the very occurrence of concerns around the functioning of the school demonstrates a clear necessity for greater dialogue between communities and the state. Communities may be free to found schools which serve local needs, but under the 
structures around free schools they are also positioned as ultimately accountable should problems occur. Given that Muslim schools have largely been excluded from the statemaintained sector, prior experience and expertise around providing mainstream faith schooling is not likely to be present within communities looking to establish Islamic free schools. In many senses, the structures around free schooling seem to be too 'free'. Responsibility for any issues of concern is instantly attributed to the school, rather than the absence of support and guidance from the state. Thus, whilst Muslim communities might be making objective gains, the structures around free schools leave these communities vulnerable to public criticism and Islamophobic media narratives where the mechanisms around free schooling reveal themselves to be inadequate. Thus, such mechanisms are inadequate for furthering the expansion of mainstream, state-funded Islamic schooling in a way which politically enfranchises British Muslims through joint-enterprise partnerships with the state. We may have more state-funded Muslim schools, but the nature of these emergent partnerships is such that accountability is not shared where these structures fail. But there is a more serious issue here. The uber-neoliberal foundations which underpin free schools represent the epitome of passivity to Islamophobic discourses which demarcate the boundaries of possibilities for expanding mainstream British Islamic schools for Muslim communities. It is through this passivity, a political act in itself, that the state has acted to position itself in opposition to the interests of British Muslims.

\section{In conclusion: state-funded Muslim schools as a site for increasing educational and political enfranchisement for British Muslims?}

Two key points are at the centre of the arguments manifested in this paper. Firstly, British Muslim communities exist in a political climate within which counter-terror strategies function against a backdrop comprised of media narratives around the 'war on terror'. This complex environment has significant implications for the political equity available to British Muslims as stakeholders in the state. Whilst master narratives may reinforce the notion of Britain as being a political democracy which advocates freedom of speech, (a principle that, crucially, was at the centre of media debates following the Charlie Hebdo attacks in Paris), in reality the political voices of Muslims are constrained. Counter-terror strategies work in conjunction with media narratives around the 'war on terror' to ensure that being Muslim and speaking out against the state carries with it the risk of being labelled as a threat to national security. This wider climate has permeated education through particular manifestations of the Prevent strategy which have culminated in a culture of surveillance around Muslim children in education. These effects are discursive, in that Muslim interests come to be positioned at the margins of educational provision. One of the ways that this has been manifested is through the misalignment between policy rhetoric and outcomes in terms of both numbers of Muslim schools and the nature of the partnerships they embody with the state.

The second key point at the centre of the argument is that state-funded Muslim schools represent important opportunities for the state to acknowledge and redress the wider political and educational inequity experienced by British Muslims through actively entering into partnerships with Muslim communities. Progress in the 1998-2010 period was slow enough to raise questions about how far New Labour actually were interested in increasing numbers of state Muslim schools. However, for those that were successful, the resulting voluntary-aided schools represented more of a partnership between local government and 
communities than those currently offered through free schooling, and allowed (at least in principle) for schools to seek support and guidance where needed as part of a localised network of institutions. Whilst numbers of Muslim free schools have increased in the post2010 era, state involvement in these partnerships is minimal. The argument here is that increasing the numbers of state-funded Muslim schools at all represents an important step in increasing the educational enfranchisement, and by proxy the political equity, of British Muslims. However, it is important to consider the power dynamics around responsibility and accountability manifested in the new and emergent mechanisms around free schools and the implications that this might have for Muslim communities within wider political climates characterised by anxieties around the 'war on terror'.

\section{References}

Adams, R. 2013. "Government Shuts Free School amid Claims Taxpayers' Money Was Wasted." The Guardian.

http://www.theguardian.com/education/2013/dec/13/government-shuts-free-schooldiscovery-west-sussex.

Allen, C. 2010. "Islamophobia: from K.I.S.S. to R.I.P." In Thinking through Islamophobia: Global Perspectives, edited by S. Sayyid and A. Vakil, 51-64. C. Hurst \& Co Publishers.

AMS. 2014. "Data from the Association of Muslim Schools UK website as of October 2014." http://ams-uk.org/muslim-schools/.

BBC. 2013. "Al-Madinah Free School in Derby Labelled 'Dysfunctional' by OFSTED." October 17, 2013. http://www.bbc.co.uk/news/uk-england-derbyshire-24548690.

Beckett, A. 2012. "Bradford Free School Fiasco: The Hard Lessons Learned." The Guardian. http://www.theguardian.com/education/2012/sep/10/bradford-free-school-fiasco-lessons.

Bolton, P. 2013. Converter Academies: Statistics, December 6, 2013. London: House of Commons Library.

Breen, D. 2009. "A Qualitative Narrative of the Transition from Independent to Voluntaryaided Status: A Problem for the Concept of the Muslim School." In Islam in Education in European Countries - Pedagogical Concepts and Empirical Findings, edited by A. A. Veinguer, G. Deitz, D. Jozsa, and T. Knauth, 95-112. Berlin: Waxmann.

Breen, D. 2013. "State-funded Muslim Schools: Stakeholders and Legitimacy in the UK Context." In Religion in Education - Innovation in International Research, edited by J. Miller, K. O'Grady, and U. McKenna, 41-57. Oxon: Routledge.

Breen, D. 2014. "British Muslim Schools: Institutional Isomorphism and the Transition from Independent to Voluntary-aided Status." In Advancing Race and Ethnicity in Education, edited by R. Race and V. Lander, 32-46. Hampshire: Palgrave-Macmillan. 
CES. 2012. Collecting Data on Catholic Schools and Colleges. Catholic Education Service. http://www.catholiceducation.org.uk/news/ces-blog/item/1000075-collecting-data-oncatholic-schools-and-colleges.

Chadwick, P. 2012. The Church School of the Future Review. Church of England Archbishop's Council, Education Division.

CofE. 2013. Church Schools and Academies in England and Wales. Church of England. Copyright: Archbishop's council. http://www.churchofengland.org/education/churchschools-academies.aspx.

Coughlan. 2007. "Education, Education, Education." BBC News, May 14, 2007. http://news.bbc.co.uk/1/hi/education/6564933.stm.

Crenshaw, K. 2002. "The First Decade: Critical Reflections, or "a Foot in the Closing Door"." In Crossroads, Directions and a New Critical Race Theory, edited by F. Valdes, J. McCristal Culp, and A. Harris, 9-31. Philadelphia, PA: Temple University Press.

Crenshaw, K., N. Gotanda, G. Peller, and K. Thomas, eds. 1995. Critical Race Theory: The Key Writings That Formed the Movement. New York: Free Press.

DCSF. 2007. Faith in the System: The Role of Schools with a Religious Character in English Education and Society. London: Department of Children Schools and Families.

DfEE. 2001. Schools Building on Success: Raising Standards, Promoting Diversity, Achieving Results. Norwich: Her Majesty's Stationary Office.

DfES. 2002. Regulatory Reform (Voluntary-aided Schools Liabilities and Funding) (England) Order 2002. London: Department for Education and Skills.

Dooley, P. 1991. "Muslim Private Schools." In Tradition, Change and Diversity, edited by G. Walford, 90-101. London: Chapman.

Fekete, L. 2004. "Anti-Muslim Racism and the European Security State." Race \& Class 46 (1): 3-29.

Gillborn, D. 2005. "Education Policy as an Act of White Supremacy: Whiteness, Critical Race Theory and Education Reform." Journal of Education Policy 20 (4): 485-505.

Gillborn, D. 2008. Racism and Education: Coincidence or Conspiracy? London: Routledge.

Helm, T., M. Taylor, and R. Davis. 2011. "David Cameron Sparks Fury from Critics Who Say Attack on Multiculturalism Has Boosted English Defence League." The Guardian, February 5, 2011. http://www.guardian.co.uk/politics/2011/feb/05/david-cameron-speech-criticisededl. 
Hussain, Y., and P. Bagguley. 2012. "Securitised Citizens: Islamophobia, Racism and the 7/7 Bombings." The Sociological Review 60 (4): 715-734.

Kershaw, I. 2014. Investigation Report: Trojan Horse Letter - Report of lan Kershaw of Northern Education for Birmingham City Council in Respect of Issues Arising as a Result of Concerns Raised in a Letter Dated 27 November 2013, Known as the Trojan Horse letter.

Kundnani, A. 2009. Spooked - How Not to Prevent Violent Extremism. Institute of Race Relations.

Meer, N. 2007. "Muslim Schools in Britain: Challenging Mobilisations or Logical Developments." Asia Pacific Journal of Education 27 (1): 55-71.

Meer, N. 2009. "Identity Articulations, Mobilization, and Autonomy in the Movement for Muslim Schools in Britain." Race Ethnicity and Education 12 (3): 379-399.

Meer, N., and D. Breen. Forthcoming. Muslim Schools in Britain: Between Mobilisation and Incorporation.

Meer, N., and T. Modood. 2009. "Refutations of Racism in the 'Muslim Question." Patterns of Prejudice 43 (3-4): 335-354.

Modood, T. 1994. "Political Blackness and British Asians." Sociology 28 (4): 859-876.

Modood, T. 1998. "Anti-essentialism, Multiculturalism and the 'Recognition' of Religious Groups." Journal of Political Philosophy 6 (4): 378-399.

Modood, T. 2005. Multicultural Politics: Racism, Ethnicity and Muslims in Britain. Edinburgh: Edinburgh University Press.

Modood, T. 2008. "A Basis for and Two Obstacles in the Way of a Multiculturalist Coalition." The British Journal of Sociology 59 (1): 47-52.

Modood, T., and P. Werbner. 1997. The Politics of Multiculturalism in the New Europe: Racism, Identity and Community. Hampshire: Palgrave Macmillan.

Parekh, B. C. 2000. The Future of Multi-ethnic Britain: Report of the Commission on the Future of Multi-ethnic Britain. London: Profile Books.

Parker-Jenkins, M., D. Hartas, and B. A. Irving. 2005. In Good Faith, Schools, Religion and Public Funding. Hampshire: Ashgate.

Runnymede. 1997. Islamophobia - A Challenge for Us All. London: Runnymede Trust.

Sayyid, S. 2010. "Out of the Devil's Dictionary." In Thinking through Islamophobia: Global Perspectives, edited by S. Sayyid and A. Vakil, 5-18. Texas: Cinco Puntos Press. 
Sian, K. P. 2015. "Spies, Surveillance and Stakeouts: Monitoring Muslim Moves in British State Schools." Race Ethnicity and Education 18 (2): 183-201.

Swann, M. 1985. Education for All: The Report of the Inquiry into the Education of Pupils of Children from Ethnic Minority Groups. London: HMSO.

Thomas, P. 2009. "Between Two Stools? The Government's 'Preventing Violent Extremism' Agenda." The Political Quarterly 80 (2): 282-291.

Tinker, C. 2009. "Rights, Social Cohesion and Identity: Arguments for and against State-funded Muslim Schools in Britain." Race, Ethnicity and Education 12 (4): 539-553.

UK Government. 2005. The Schools White Paper: Higher Standards, Better Schools for All. London: Her Majesty's Stationary Office.

UK Government. 2014. Types of School: Free Schools. UK Government website. https://www.gov.uk/types-of-school/free-schools.

UK Parliament. 1998. School Standards and Framework Act. London: Her Majesty's Stationary Office.

UK Parliament. 2010. The Academies Act. London: Her Majesty's Stationary Office.

Walford, G. 2003. "Muslim Schools in Britain." In British Private Schools: Research on Policy and Practice, edited by G. Walford, 156-176. London: Woburn Press. 